\title{
Fort McMurray, Wood Buffalo, and the Oil/Tar SANDS: Revisiting the Sociology of "COMMUNity"
}

\section{Introduction to the Special Issue}

\author{
SARA Dorow \\ SARA O'SHAUGHNESSY
}

Community, it seems, is a passport to both Arcadia and Utopia.

(Schofield 2002)

In the first decade of the 21 st century, more than one hundred billion dollars were poured into the business of extracting bitumen at increasingly higher rates from the third largest known deposit of oil and by some estimates the largest industrial mega-program in our planet's history - the Athabasca Oil Sands formation in northeast Alberta. Fort McMurray is the urban service area that sits at the heart of the Florida-sized region under which these deposits lie (for a series of maps, see http:// www.fortmcmurraychamber.ca/faqs.html). It has also become a Canadian and even global household name that conjures the whole of the oil/ tar sands, invoking larger than life scales of work, money, opportunity, destruction, development, environment, "the North." For many who live there it represents home and history, while for many others it represents work-but-not-home. For one network of transnational actors, it invokes a behemoth that must be stopped, or at least slowed down, and for yet another transnational network, it invokes a lucrative if sometimes risky investment opportunity.

It is this particular political and cultural economy that prompts us to take the oil/tar sands region and Fort McMurray (Regional Municipality of Wood Buffalo), Alberta as a case through which to interrogate the sociology of "community." Indeed, it was just before and during the same period in which the oil/tar sands industry rose to global prominence and infamy that sociology and a related range of social science 
and humanities disciplines began grappling anew with the meaning and prevalence of "community" in official, popular, and academic discourses. The term was revived for a broad range of scholarly interests, from its significance to new technologies of power, government, and affect (Rose 1999; Larner 2000; Joseph 2002; Ahmed 2004) to its alleged demise in the face of heightened consumerism and individualism (Putnam 2000; McBride 2005); and from its intensified and restructured geospatial relations with circuits of capital, technology, and people (Gustafson 2006; Graham and Healey 1999) to its political potentialities across the differences of identity implied by these intensified relations (DeFilippis 2004; Etzioni 2007).

Whatever the locus or direction of interest in "community" whether a nostalgia for what is lost, a suspicion of what is excluded or occluded, or a hope for what could be - one thing is sure: "community acts as a powerful code word in the organization of contemporary society" (Pandey 2006:255). It is thus essential, as Creed (2006:4) has asserted, "to look inside this seemingly transparent term and discover the associations that are, as it were, hidden in plain view." For the pivotal anthology that Creed edited, and for this special issue, discourses and practices of community must be understood alongside shifting relations of state and market, public and private, society and economy. (The original call for papers for this special issue was entitled "Community 'between' State and Market.")

There are, of course, divergent epistemological and disciplinary approaches to assaying these broad dynamics. We could, for example, ask in broad strokes about how shifting political and economic forces entail, produce, and/or take up particular concepts or discourses of community (Rose 1999; Joseph 2002; Watts 2006). From quite a different paradigmatic vantage point we could ask how those shifting forces transform, enhance, squeeze, and/or eviscerate the lived possibilities of community and community well-being (DeFilippis 2004; Putnam 2007; Turner and Brownhill 2004). We think it is important to consider these as cousin paradigms whose relationship is crucial but fraught. Making claims to community depends on some similitude between what is imagined and what is recognized in experience (Amit 2002); community requires conscious symbolic and identity work, but the idea of it can only be achieved if such a community is felt to preexist (Rose 1999:177).

This relationship between the substantive/experiential and the discursive/productive sides of community demands that we attend to structural/institutional factors without either reducing any one of them to the other or creating rigid causal relationships among them (Vaisey 2007). It is this complex dynamic between the lived practice and the symbolic im- 
aginary of community, and how this dynamic is produced in and through, for and against, the political economy of one global oil complex, that provides a key common thread across the contributions to this special issue.

\section{COMmunity AND Sociology}

Many readers will call to mind Ferdinand Tönnies' ([1887] 1957) Community and Society, often thought of as the first sociological treatise on community. Various sociologists since his time have grappled with the questions of small and large scales of association, similarity and difference, proximity and distance, change and permanence, "natural" and "rational" bonds, emotion and regulation that were so central to the concepts of Gesellschaft and Gemeinschaft. Arguing that Tönnies' work is inadequate to rigorous social analysis and has become overly laden with romantic notions of community (set against the cold regulation of "society"), Steven Brint (2001) has attempted to reinvigorate a more Durkheimian concept of community to develop a typology of subtypes (e.g., place- versus choice-driven, activity- versus belief-driven) amenable to scientific study and generalization. Along similar structural lines, Putnam's Bowling Alone (2000) theorizes the "collapse and revival of American community" (the subtitle of his much lauded and reviled book) via the concepts of social capital and social network. Vaisey (2007) revives Tönnies and Weber in pursuit of a balance between structural and experiential understandings of the moral bonds of community.

By wearing a more genealogical pair of sociological lenses, Nikolas Rose (1999) reminds us that variance in sociological interest in the loss, revival, and transformation of community itself requires theorization. From Tönnies in the late 19th century to Etzioni and the "third sector" scholars in the late 20th, "[t]he community appealed to is different in different cases: differently spatialized and differently temporized" (Rose 1999:172). This is, of course, because theorists and the "community" they theorize are products of their own political and economic times. We ignore at our peril the variable conditions of state and market and the raced, classed, and gendered relations of power that shape the political possibilities and social inequalities of community-making (McLean et al. 2002; Williamson et al. 2002), let alone the ways in which we imagine we can conduct social scientific inquiry into these processes.

Given the many debates and ambiguities that attend the term, it appears difficult to say anything meaningful at all about community as a practice, an imaginary, and a concept. But we must start somewhere. 
This special issue starts with the oil/tar sands zone in northeast Alberta. The fact of this massive industrial program, appearing as it does in late 20th and early 21 st century Canada, emphasizes and even demands specific versions of the questions about "community" referred to above. For example:

- If community is imagined as a moral space of voluntarism situated between state and market (Rose 1999, cited in Schofield 2002), what characteristics are assigned to such a space in a neoliberal resource economy?

- If community is claimed via shifting boundaries of inclusion and exclusion (Creed 2006; Bauman 2001), and is in this way continuous with the terms of family and nation (see, for example, Shever 2008), how does this play out in the context of highly mobile work and rapid growth? How does it play out in the context of masculinist and racialized relations of global labour (O'Shaughnessy 2011; Dorow 2013 forthcoming)?

- How does place-contingent resource extraction, production, and distribution shape the spatialized experiences and understandings of community (Dorow and Dogu 2011; Shields 2012), i.e., its de- and re-territorialization?

- What images and representations of community become dominant and contested when the "local" economy is a global spectacle, i.e., receives constant public international attention (from the media, and from transnational economic, political, and environmental institutions)?

- How do indigenous identities and colonial histories encounter industrial expansion, extractive capital, and environmental activism, and with what implications for community?

- If Fort McMurray is a social epicenter of homo energeticus (HaluzaDelay 2012), what is the political potential for new assemblages and formations of community, in northeast Alberta and beyond?

"Community" is a discourse, an ideology, a claim, a practice, an assemblage (see Schofield 2002 on the latter). Always it is in contention, its shifting boundaries crucial to claiming its content. Yet as Creed (2006) tells us, it always seems to suggest a place, a group of people, and a feeling in some combination or another. The articles in this special issue adopt differing methodological and theoretical starting points to the question of community, but they all refer in some way to these three facets of the term, using Fort McMurray-and-the-oil/tar-sands as their window for doing so. 


\section{The Oil/Tar SAnds}

In the Fort McMurray region, people, place, and feeling are intertwined not only with each other but also with the fact of the oil/tar sands. We have chosen the "slashed" reference because the two terms - oil sands, tar sands - circulate in dialectically important and contentious ways, and articulate to ideas of community in ways both similar and dissimilar. We aim to keep this tension alive. In her discourse analysis of the two terms as they appear in contemporary documents and websites, Kidner (2010) found that while tarsands tends to be associated with "critic, environmentalist, misinformed, radical, young socialist," oilsands tends to be associated with "supporter, industry, open-minded, government, pro-business, capitalist." This divide is complicated by the fact that "tar sands" was in standard usage during the first boom of the 1960s and 1970s; no wonder, then, that long-time workers in Fort McMurray are sometimes corrected on their parlance.

No matter what you call it, this industrial mega-program in northeast Alberta is about the extraction and separation of bitumen from the sandy soil beneath the muskeg and boreal forest through one of two methods: open-pit mining on the surface, and in situ wells that inject steam and chemical solvents to coax bitumen from reservoirs deeper under ground. Out of these processes come 1.6 million barrels of oil per day (Government of Alberta 2011) that might be upgraded in Alberta but are mostly sluiced and piped elsewhere in Canada or the United States for processing and marketing, with the Pacific Rim as the next horizon (including, as we write, via pipelines that might go east or north). Protests over the Keystone XL and Northern Gateway pipelines, reaction to Alberta Premier Alison Redford's "national energy strategy," debate over the sale of Nexen to the Chinese state-owned oil company CNOOC, and the growth of the Idle No More movement have heightened the political and environmental specter of the oil/tar sands.

Chris Joseph (2010) has termed the oil/tar sands a mega-program in order to capture its character as an organically evolving set of megaprojects. There are some one hundred active sites of production (www. oilsandsdevelopers.ca) involving several dozen companies, many of them foreign-owned. By late 2011 a total of \$133.6 billion dollars had been invested in the oil/tar sands (Calgary Herald 2012), and this is expected to top $\$ 200$ billion by 2030 ; by the mid-2020s, total production is expected to exceed three million barrels per day with the majority of that product coming from in situ extraction (Honarvar et al. 2011).

Any consideration of the meaning of these forecasts must, however, take into account that they change with economic and technological 
conditions, and that their implications for imagining or practicing community are contingent on the political and cultural economies in which capital operates and circulates. As we write this in early 2013, the media warns that clogged pipelines, decreased US demand, and lower than expected oil prices spell hard times for the industry and thus for Alberta's provincial budget. These sorts of historical contingencies make for constantly shifting projections and timelines for development and thus (the logic goes) bring uncertainty to imagining and planning for "community" in the region. For example, the projected transition from the construction phase to the operations and maintenance phase of the industry inches ever farther into the 2020s. The regional municipality in which Fort McMurray sits makes no secret of its frustration over the resulting difficulties in population, housing, and infrastructure management (see, for example, Regional Municipality of Wood Buffalo 2011). At a somewhat broader scale, assessments of the viable economic lifespan of the oil/tar sands range from fifty to several hundred years.

The concentration of activity and meaning around one globally powerful commodity - sometimes referred to as resource dependency - means that the dominant social imaginary of community and the business of oil extraction become intertwined in multiple, specific ways. An Oil Sands Trade Show held in Fort McMurray in September 2012 averred that the event was the "business gateway to the oil sands community" (oilsandstradeshow.com). More than this, much of the formal community infrastructure of Fort McMurray and smaller surrounding communities has been and continues to be funded directly or indirectly by the oil industry. The aforementioned trade show was held in what is touted as one of Canada's most state-of-the-art leisure and recreation centres, a municipal-industry partnership called Suncor Community Leisure Centre that also houses the Syncrude Aquatic Centre and is soon to sport a new wing called Shell Place. While the provincial government has injected more than four hundred million dollars into municipal infrastructure following on the recommendations of the pivotal 2006 report Investing in Our Future: Responding to the Rapid Growth in Oil Sands Development (commonly known as the Radke Report), its relationship to the place is inextricably bound to that of corporations, which have increasingly engaged in public-private partnerships.

\section{Fort McMurray (Wood Buffalo) as a Case}

Fort McMurray is technically a hamlet and the urban service area to the much larger Regional Municipality of Wood Buffalo (RMWB), an area of 68,454 square kilometers that includes, at least officially, ten less 
populated and mostly Aboriginal settlements. We and the special issue contributors variously refer to Fort McMurray and/or Wood Buffalo, a slippage of terminology that speaks to the very political history of oil development. The formation of the RMWB in 1995 allowed the expanse of the oil/tar sands industry tax base to be captured and managed in Fort McMurray as the governing seat of the region. As an editorial introduction to a special 15th anniversary supplement to Oilsands Review put it, prior to amalgamation "the center of community was not able to reap the benefits of corporate taxes paid regionally, and [was] therefore challenged to provide adequate support for its residents" (Jaremko 2010:9). This challenge was becoming all the more apparent in the late 1990s as new tax breaks for industry attracted new investment.

It is during this period of rapid post-amalgamation development of the oil/tar sands that most of the research represented in this special issue took place. At the height of the boom in 2007, residents of Fort McMurray spoke of a boomtown on steroids, of a place experiencing an adolescent phase, and/or of a lack of time to catch up to the pace of development. Some blamed various levels of government for a lack of planning or regulation; some blamed the more than twenty thousand mobile workers who seemed to be there only to work and make money (and in some cases, to take jobs) rather than to "invest" in the community (Dorow and Dogu 2011). Such growth, stress, and volatility make for a complex politics of social and environmental responsibility. When many of the people crowding the emergency room carry health cards from other provinces and local residents can't get access to a doctor, what happens to the calculus of community inclusion and responsibility? When a labour shortage wrought by the unbridled development of oil is filled with people who are ineligible for citizenship, whence the translation of "opportunity" into community? When small Aboriginal settlements are surrounded by the seemingly inevitable development of oil mega-projects, what comes to constitute value and well-being?

The socioeconomic impacts of development on Fort McMurray and the RMWB in many ways reflect those found across the literature on boomtowns. These include family stress and decreased psychological wellbeing (Davenport and Davenport 1981; Parkins and Angell 2011; Shandro et al. 2011), increased crime rates (Endo et al. 1984; Hunter et al. 2002), infrastructure pressures on everything from sewage systems to childcare (Reese and Cummings 1979; England and Albrecht 1984; Shandro et al. 2011), high turnover and mobility (Krahn and Gartrell 1983; O'Faircheallaigh 1995; Pirotta 2009), and sometimes rapid increases in cost of living and housing costs in particular (Lawrie et al. 2011; Ryser and Halseth 2011). In practice, of course, these indicators are 
diverse in both their production and effects (Randall and Ironside 1996), and thus require critical analysis of their assumptions and silences. The contributions to this special issue, for example, address community impacts both of and on mobile workers (Winters and Major, Foster and Taylor), and critically explore narratives of abject youth (Lozowy, Shields, and Dorow) and oily monsters (Westman). In his epilogue to the issue, Mookerjea more pointedly unravels the politics through which any such set of indicators is produced, but also potentially challenged.

Fort McMurray and Wood Buffalo also deviate from the expected characteristics of resource-dependent communities. With the continual expansion and projected life spans of bitumen mining and in situ extraction, the region does not fully follow the conventional boom-bust patterns of single industry resource towns in Canada. With a current population estimated at 80-100,000 (depending on who is counted, and by whom - see Haan 2012), Fort McMurray is increasingly urban and suburban, with ambitious plans underway to develop a "sustainable, beautiful, competitive, connected" city (Regional Municipality of Wood Buffalo 2012) complete with high rise condos, urban shopping amenities, and green recycling and transportation infrastructures. With labour migration patterns that are not only regional but international, Fort McMurray is a diverse city where more than sixty languages are spoken. Like other boomtowns the region has a high "shadow population" of mobile workers in industrial and other sectors that by most estimates make up a quarter of the population of the RMWB.

Given the size of the oil mega-program as well as the size of the urban service area, local infrastructural stresses are of a scale and longevity not found in most of Canada's northern resource regions. Fort McMurray is a resource city, projected to become the third largest and most northern municipality in Alberta (after Calgary and Edmonton). This particular economic geography has spawned the joke that Fort McMurray is the world's largest cul-de-sac. Indeed, an ever-expanding transportation infrastructure of airstrips and highways carries people and equipment and parts in and out of the region. At the same time, the culde-sac metaphor erases the lived histories of Cree, Chipewyan, Dené, and Métis people that span the region and the more recent history of Fort McMurray as a southern transportation point for materials and people headed north.

The idea of community in Fort McMurray is thus inevitably tied to colonial imaginaries of Canada's "developed" South and "frontier" North (Shields 1991); to debates over the prominent place of resource extraction in the Canadian political economy, in which figure the hopes and fears of the oil/tar sands as "Canada's economic engine"; to tensions 
over municipal, provincial, and federal jurisdictional control; to complex transnational structures of labour and production, i.e., to global imaginaries of "North" and "South"; and to battles over Aboriginal rights and environmental impacts. The latter was especially responsible for imprinting the oil/tar sands in the global imaginary by 2007 and 2008 .

Sustained global critique of social and especially environmental concerns has put Fort McMurray (as a moniker for both the residential community and the oil/tar sands) into the North American media limelight more consistently than most other resource communities. This has created local anxieties about, and has prompted a series of official responses to, the reputation and representation of the community. It can also mean that the needs of particular populations and communities are neglected, co-opted, and/or circumscribed, which Winters and Major analyze among immigrants and Newfoundlanders, Foster and Taylor consider with respect to temporary foreign workers, Lozowy et al. explore among youth, and Westman addresses in several small Aboriginal communities at the edges of the oil/tar sands zone.

If taken as a case of a boomtown, Fort McMurray can be analyzed from multiple angles. Following the typology of case studies offered by Flyvberg (2006:232), it might be taken as a paradigmatic case that highlight[s] more general characteristics of the society in question; many of the socioeconomic and environmental issues facing the region are equally noted in other parts of Alberta and North America, as well as in historical cases like Gillette and Rock Springs, Wyoming, and Craig, Colorado (Kohrs 1974). Young and Matthews (2007:177) argue that resource frontiers provide excellent case studies for exploring and theorizing neoliberal reform more generally "because these are sites where the political and economic tensions of capitalism manifest in exceptionally vivid and observable forms." Fort McMurray might also hold scholarly value as an extreme case that conveys a point in dramatic fashion, and/or as a critical case that has strategic importance (2007:229-232) because of its particular geographical and social location, global industrial landscape, and other political exigencies as noted above. Understanding this trajectory, including the increasingly stratified and cosmopolitan populations and more globalized networks of political and economic actors now characterizing resources communities that were previous characterized by their homogeneity and regionalism, is crucial to understanding community wellbeing as well as various imaginaries and constructions of it.

However, this special issue does not simply approach Fort McMurray and the oil/tar sands zone as a case (paradigmatic, exceptional, or any other variety) of resource boomtown. One important contribution of case examples is the opportunity to explore the various and even unexpected 
power relations embedded and/or circulated throughout multiple structures and actors. In other words, case studies provide intensive foci on the specific context while allowing new questions to be generated. We might better think of ethnographic case studies, then, as "windows into constitutive processes, and a means of reconfiguring understandings and practices" (Hart 2004:97).

The contributions to this issue generate new questions because they approach Fort McMurray and the RMWB as a particular but deeply interconnected node of globalized and historical activity. This resonates with Doreen Massey's two-sided reminder: "communities can exist without being in the same place" and at the same time, even in those rare instances where places do house fairly coherent communities, "this in no way implies a single sense of place" (1994:153-154). Indeed, our authors provide multiple angles on "community" in this case - as urban service area to the oil sands, as work destination for tens of thousands of domestic and international workers, as site of continuing colonial contestation over human relations to land and animals, as visually hyperrepresented and fetishized, as space in which boundaries of belonging are entrenched, negotiated, and contested.

\section{Discerning People-Place-Feeling: The Contributions to the Special ISSUE}

The contributors to the special issue variously identify as sociologists, geographers, or anthropologists and would probably all describe themselves as interdisciplinary. Such breadth is not surprising; some of the richest critical analyses of community in recent years have come from cultural studies, geography, and other fields less hampered by some of sociology's predictable treatments of forms of capital, ascribed identities, and social solidarity. At the same time, the contributions hold in common a commitment to qualitative methodologies. Their deployments of interviews, ethnographic participation, and/or visual methods make instructive tours through some of the less obvious meanings and exigencies of community.

Wittgenstein averred that "a good guide will take you through the more important streets more often than he takes you down side streets; a bad guide will do the opposite. In philosophy I'm a rather bad guide" (quoted in Flyvberg 2006:239). Happily, the contributors to the special issue are also "bad guides." They offer tours of side streets that are vigilantly attentive to broader pathways of transnational labour markets, global media representations, petro-capitalism, and class politics. They 
point to myriad sites of production, social reproduction, consumption, representation, and speculation both within and beyond the oil/tar sands region, always keeping in their sights the politics of community itself as a contradictory relation of people-place-feeling.

The first two articles belie the generic association of community with people and place by examining the precarious and stratified borderland between inclusion and exclusion. Indeed, they show that the very claim to local community cloaks its layers of race, gender, and class. This might even apply when "local" is proudly diverse, e.g., when long-time residents of Fort McMurray refer to having one of the oldest mosques in western Canada and a history that goes beyond oil, to trapping, shipping, salt mining, frontier survival. But these discourses falter in the face of the rapid growth and diversification of the population over the last decade, in which the contiguousness of "local" and "diverse" is crosscut by new global divisions of labour. They also falter in the face of the contemporary saturation of oil, which is the community's "bread and butter": its rapid expansion supplies employment, directly or indirectly, to $65 \%$ of the working population, and most everyone assumes that this, in turn, implies and requires a highly mobile population.

The Regional Municipality of Wood Buffalo is undeniably a work destination. Its many mobile workers live in work camps near industry sites - many on a "fly in, fly out" basis — or in apartments and basement suites in Fort McMurray. While typically imagined as skilled trades workers, they also include professionals and retail and service workers. As shown by Winters and Major as well as Foster and Taylor, the high numbers and diverse make-up of mobile workers - who might be seasonal workers from rural or reserve areas of Alberta, Somali-Canadians who have made a secondary migration from Toronto, individuals or families from the Atlantic provinces seeking work in the wake of floundering fisheries, professionals from the oil industries of Nigeria or Venezuela, temporary foreign workers from the Philippines or China - is important to the imagined boundaries and experiences of "community."

Tracy Winters and Claire Major untangle some of the complexities of shifting class relations in the oil economy, arguing that these are obscured by notions of community that valorize individualized risk and self-sufficiency. While community is often envisioned as occupying a social space beyond the political and the economic, Winters and Major argue that "community by necessity" is in fact an organizing concept strategically employed to maintain a productive workforce within the contradictory forces of resource capitalism. The feeling of community - seen in the official branding of Fort McMurray — is produced and even saved through the economy of oil, and is at the same time necessary 
to absorbing its social externalities. Coupled with the narrative of "Fort McMurray=good jobs," the prevailing notion of community suggests that class differences are erased by the high wages associated with working class jobs and that "difference" manifests as a rich multiculturalism that enhances quality of life. Community, in this context, is positioned as the force that evens out differences and provides a buffer against the precariousness of labour patterns and the challenges of migration. Using interview data from two studies, one conducted with migrant workers from Newfoundland and the other with immigrants holding varied skill levels, the authors demonstrate that workers self-situate within these narratives. As a result, the dispossession of the workforce and their struggles for equity are hidden at the structural level, and difficult to articulate on an individual scale. Migrants from Newfoundland speak proudly of the role they play in building Fort McMurray, yet feel there is no place for them once they are no longer working. Immigrant populations, as Winters and Major show, are crucial to the narrative of Fort McMurray as a diverse and exciting community. Yet these populations face some of the most precarious and highly varied levels of support, depending in part on their skill levels. Those with the highest skill sets often find their social reproductive needs met by their employers and find it relatively easy to leave Fort McMurray, while those who are unskilled have the least security and mobility.

The particular branding of community in Fort McMurray also minimizes attention to the social costs borne by mobile workers and their families, and to the impacts on local governments, community organizations, and households across the globe that absorb the social costs of high rates of labour migration. While gender is not a major focus in any of the contributions to the special issue, Winters and Major question the gendered implications of this particular vision of community. As other work has shown, women in Fort McMurray frequently take on the normative responsibility for social reproduction and for maintaining a sense of community, despite also self-situating within narratives of individualized risks and reward. These gendered relations and their implications for social relations within and beyond the household have to be understood within the structures of masculinized work, high rates of overtime and shift work, and promises of opportunity that characterize the oil/tar sands (O'Shaughnessy 2011; Dorow forthcoming).

Jason Foster and Alison Taylor demonstrate that the experiences of temporary foreign workers also emphasize the class contradictions of community. Oil/tar sands development and the Alberta economy more generally have increasingly relied on this flexible global workforce, and yet policy and practice continue to lag behind in addressing the issues 
of inequality and exclusion that Foster and Taylor so systematically analyze. A just-in-time approach to labour supply and the existence of double standards in labour certification do not jive with the multicultural community of opportunity that is commonly imagined. In considering "community" via the sociology of work, especially that of global mobile work, Foster and Taylor demonstrate the "differential exclusion" experienced by trades workers who are in the Fort McMurray area under the Temporary Foreign Worker Program (TFWP). Precarious work and citizenship status along with other forms of racialized marginalization both reveal and entrench the inside and outside of community. Foster and Taylor remind us that this increasingly common global experience consistently places workers "in between" communities. However, they are careful neither to romanticize place-based community nor to cast temporary foreign workers as victims. Rather, the agency of TFWs has the potential to trouble the correspondence between place and community precisely because it brings into view the importance of economically driven place affiliations (such as living in a work camp with a limited path to citizenship status) to the social imaginary of community. While Foster and Taylor do not directly argue that local or national community might in fact be built via the codified instrumentalization of some segments of workers, their analysis does help us wonder about the forms of exclusion that underwrite continuities between the imaginary and the actualization of community (cf. Amit 2002).

These first two articles show us how community is defined through norms and assumptions of long-term residence, cultural sameness, economic opportunity, and/or fluid work-life relations. In training their sights on the social relations and labour striations of oil production, the authors analyze community as a particularized and bounded configuration of people, place, and feeling. The next two contributions also turn our attention to the powerful historical force of oil/tar sands development, but by focusing on photographic images and mythological stories, respectively, they illuminate the slippery, unpredictable, and productive fault lines, excesses, and proliferations of community. These nuanced analyses focus on populations whose experiences of community are often unrecognized or unrecognizable. In this way, the two articles cut sideways through hand-wringing about the fate of young people and indigenous people in single resource economies.

Andriko Lozowy, Rob Shields, and Sara Dorow offer a piece that is at once methodological and theoretical. Their work derives from a photo project that put cameras into the hands of a small but diverse group of youth and asked the question, Where is Fort McMurray? They consider the apparatus of the camera as not just catalyst but also actor that 
assembles people (including researchers) in relationships to each other and to place. The camera takes on particular significance in a context where affiliations among people and place are always already affectively produced in relation to oil, including, importantly, its larger-thanlife "visualicity." Two specific photos and the stories of their production and circulation are the centrepiece of the article. By learning how the images were negotiated and given meaning as the project unfolded, we learn how youth are both subjects and objects of community-making in boomtown Fort McMurray. Lozowy et al. assert that the oil/tar sands is a reference point for the youth, but not necessarily because of the visual spectacle it has become or because of the external gaze it has invited on Fort McMurray. For the youth, the facts of rapid development and high mobility are woven into the mundane fabric of their lives and given poignancy through the camera lens. In the process, they remind us that the meaning of community is contested and fungible, and that places become such through multiple co-existing productions of space. The authors suggest that this is made possible by the particular positioning of youth (which is too often diminished or, conversely, valorized), but also by the invitation to work with cameras.

In the fourth and final of the main articles, Clinton Westman uses the "cautionary tales" of Aboriginal storytelling to lay bare the relations of power that actively but ineffectually obscure particular communities and ideas of community. Deploying the figures of the Trickster and Windigo, he traces the twists and turns of oil's effects on several small Aboriginal settlements that sit just on the edge of the oil/tar sands zone. Borrowing from Lévi-Strauss, he explicates forms of community integration, disintegration, and (re)mediation. Local experiences and narratives present us with the uneven forces of insatiable oil appetites and longstanding subsistence on the land. They also reveal the precariousness of alleged solutions to waste in the oil sands. While sometimes technologically elegant, these solutions begin to look ridiculous when considered in the light of community defined in an altogether different fashion: as valuing efficiency within the relations of exchange and respect among human and nonhuman. Westman's contribution reminds us that it is not entirely possible, nor even intellectually or politically prudent, to dismiss "community." Trickster and Windigo tales involving farts and oily monsters point to the fruitful tensions found across different concepts of community, allowing us to neither fix nor romanticize it.

Westman's research resonates in important ways with the experiences of Aboriginal settlements more squarely ensconced within the territory of oil development and the RMWB; they, too, are often conjured as immutable and singular communities in the public relations, policies, 
and programs of government, industry, and activist organizations. In practice, of course, Aboriginal "communities" in the oil/tar sands region are made up of people with multiple imaginaries of their own histories and subjectivities, as well as multiple and overlapping relationships to the oil industry that range from opposition to accommodation to entrepreneurialism.

Each of these four main articles takes up different populations, issues, and methods to interrogate the people, place, and feeling of community. Certain concepts and questions appear regularly across them - references to capitalism, to colonialism, to identity, to politics. It is the continuities across these analytics that Sourayan Mookerjea addresses in an invited concluding essay — what we might think of as a commencement address to the special issue that reflects on what has been and what could be. His epilogue picks up some of the important gaps and threads of the special issue, noting three particular questions raised by its contents: what are the implications for class politics, why the persistent return of "community," how might we retheorize community? It is this last question that drives the essay's elegant argument toward a politics in common, or what he calls a community of politics. Mookerjea is concerned with recovering "community contradictions" as a utopian project, and does so through building a dialectic of two class concepts: the multitude (à la Hardt and Negri) and the subaltern (à la Gramsci and postcolonial theory). Along the way, he creates a dialogue with the various contributions of the articles in the special issue. The question of community in the case of Wood Buffalo opens us out not only to the political and social forces of the global oil complex but also to the historical conditions of possibility for them; for Mookerjea, the possibilities of community lie in the struggle over the narrative of history, which includes a role for sociological engagement with its contradictions and utopian poetics.

Community, says Amit (2010), is "good to think with." For this special issue, it is an analytic that sheds light on specific social facets of Fort McMurray, Wood Buffalo, the oil/tar sands, and the relationships among them, without pretending to have addressed more than a fraction of ways of thinking community or of understanding the region in question. We are aware of the danger of caricaturing or alienating those who live and/ or work in the oil/tar sands zone, and who might rightly protest that their understandings and experiences of community are more complex than is portrayed. But this is a danger that inevitably accompanies the task of making community itself the object of interest, burdened as it is with so much hope and despair, certainty and uncertainty. As Mookerjea puts it, this is "not only a matter of 'community' meaning anything and therefore nothing but also [of] meaning something very specific" (p. 246). 
The tours of edges and side streets offered in this special issue attempt to raise particular questions - to make community an urgent analytic in specific ways. Each contribution develops its own conceptual questions and frameworks for thinking about community. It is our hope that these travel to other contexts, and even circulate into the region in question, including in ways we cannot possibly predict.

\section{REFERENCES}

Ahmed, Sara. 2004. Affective economies. Social Text 22(2):117-139.

Amit, Vered. 2010. Community as "good to think with": The productiveness of strategic ambiguities. Anthropologica 52(2):357-375. 2002. Reconceptualizing community. Pp. 1-20 in V. Amit, ed., Realizing Community: Concepts, Social Relationships and Sentiments. London, New York: Routledge.

Bauman, Zygmunt. 2001. Community: Seeking Safety in an Insecure World. Cambridge: Polity.

Brint, Steven. 2001. Gemeinschaft revisited: A critique and reconstruction of the community concept. Sociological Theory 19(1):1-23.

Calgary Herald. 2012. Billions in oilsands investment in Alberta. http://blogs. calgaryherald.com/2012/01/15/billions-in-oilsands-investment-in-alberta/

Creed, Gerald W. 2006. Reconsidering community. Pp. 23-48 in G.W. Creed, ed., The Seductions of Community: Emancipations, Oppressions, Quandaries. Santa Fe, NM: School of American Research Press.

Davenport, Joseph III and Judith Ann Davenport. 1981. Boom town victims: Social work's latest clients. Journal of Sociology and Social Welfare 8:150.

DeFilippis, James. 2004. Unmaking Goliath: Community Control in the Face of Capital Mobility. London: Routledge.

Dorow, Sara. Forthcoming. Gendering energy extraction in Fort McMurray. In L. Stefanick and M. Shrivastava, eds. Democracy and Governance in a Global North Oil Economy.

Dorow, Sara and Goze Dogu. 2011. The spatial distribution of hope in and beyond Fort McMurray. Pp. 271-292 in T.K. Davidson, O. Park, and R. Shields, eds., Ecologies of Affect: Placing Nostalgia, Desire, and Hope. Waterloo, ON: Wilfred Laurier Press.

Endo, Russell, Barbara L. Ellington, and Joyce McCarl Nielsen. 1984. Wife abuse in western energy boomtowns. International Journal of Sociology of the Family 14(2):269-281.

England, J. Lynn and Stan L. Albrecht. 1984. Boomtowns and social disruption. Rural Sociology 49(2):230-246. 
Etzioni, Amitai. 2007. The community deficit. JCMS: Journal of Common Market Studies 45(1):23-43.

Flyvberg, Bent. 2006. Five misunderstandings about case-study research. Qualitative Inquiry 12(2):219-245.

Government of Alberta. 2011. Oil Sands Project Report - Wood Buffalo, August 2011. http://www.woodbuffalo.net.

Graham, Stephen and Patsy Healey. 1999. Relational concepts of space and place: Issues for planning theory and practice. European Planning Studies 7(5):623-646.

Gustafson, Per. 2006. Place attachment and mobility. Pp. 17-31 in N. McIntyre, D. Williams, and K. McHugh, eds., Multiple Dwelling And Tourism: Negotiating Place, Home And Identity. Cambridge: CABI.

Haan, Michael. 2012. Counting and contemporary governance: Introduction to the special issue. Canadian Journal of Sociology/Cahiers Canadiens de Sociologie 37(3):223-230.

Haluza-Delay, Randolph. 2012. Giving consent in the petrostate: Hegemony and Alberta oil sands. http://www.wepaste.org/Resources/JASTE4-1a Haluza-DeLay.pdf.

Hart, Gillian. 2004. Geography and development: Critical ethnographies. Progress in Human Geography 28(1):91-100.

Honarvar, Afshin, Jon Rozhon, Dinara Millinton, Thorn Walden, Carlos A. Muillor and Zoey Walden. 2011. Economic Impacts of New Oil Sands Projects in Alberta (2010-2035). Canadian Energy Research Institute Study \#124. http://www.api.org/aboutoilgas/oilsands/upload/economic impacts of new oil sands projects alberta.pdf.

Hunter, Lori M., Richard S. Krannich, and Michael D. Smith. 2002. Rural migration, rapid growth, and fear of crime. Rural Sociology 67(1):71-89.

Jaremko, Deborah. 2010. Editor's note. Wood Buffalo: Celebrating 15 Years of Alberta's Major Oilsands Municipality - a supplement to Oilsands Review. November.

Joseph, Chris. 2010. The tar sands of Alberta: Exploring the gigaproject concept. Pp. 161-164 in J.M. Piwowar, compiler, Proceedings of the Prairie Summit/Actes de Le Sommet des Prairies: Joint Conference of Canadian Association of Geographers, Canadian Cartographic Conference, Canadian Geomorphology Research Group, and Canadian Remote Sensing Society, June 1-5, Regina, SK. http://uregina.ca/prairies/assets/PrairieSummit Proceedings.pdf.

Joseph, Miranda. 2002. Against the Romance of Community. Minneapolis, MN: University of Minnesota Press.

Kidner, Keely. 2010. Oil sands or tar sands? What these words really mean in Alberta. Conference presentation, Unwrap the Research Conference, October 22-24. Fort McMurray, AB. 
Kohrs, ElDean V. 1974. Social consequences of boom town growth in Wyoming. Presented at the Rocky Mountain Association for the Advancement of Science. April, Laramie, Wyoming.

Krahn, Harvey and John W. Gartrell. 1983. Labour market segmentation and social mobility in a Canadian single-industry community. Canadian Review of Sociology 20(3):322-345.

Larner, Wendy. 2000. Neo-liberalism: Policy, ideology, governmentality. Studies in Political Economy. 63:5-25.

Lawrie, Misty, Matthew Tonts, and Paul Plummer. 2011. Boomtowns, resource dependence and socio-economic well-being. Australian Geographer 42(2):139-164.

Massey, Doreen. 1994. Space, Place, and Gender. Minneapolis, MN: University of Minnesota Press.

McBride, Keally D. 2005. Collective Dreams: Political Imagination and Community. University Park, PA: Pennsylvania State University Press.

McLean, Scott L., David A. Schultz, and Manfred B. Steger, eds. 2002. Social Capital: Critical Perspectives on Community and "Bowling Alone." New York: New York University Press.

O'Faircheallaigh, Ciaran. 1995. Long distance community in resource industries: Implications for Native peoples in Australia and Canada. Human Organization 54(2):205-213.

O'Shaughnessy, Sara. 2011. Women's Gendered Experiences of Rapid Resource Development in the Canadian North: New Opportunities or Old Challenges? $\mathrm{PhD}$ Thesis, University of Alberta. http://hdl.handle.net.login. ezproxy.library.ualberta.ca/10048/1958.

Pandey, Gyanendra. 2006. The politics of community: Some notes from India. Pp. 255-277 in G.W. Creed, ed., The Seductions of Community: Emancipations, Oppressions, Quandaries. Santa Fe, NM: School of American Research Press.

Parkins, John R. and Angela C. Angell. 2011. Linking social structure, fragmentation, and substance abuse in a resource-based community. Community, Work \& Family 14(1):39-55.

Pirotta, Julie. 2009. An exploration of the experiences of women who FIFO. The Australian Community Psychologist 21(2):37-51.

Putnam, Robert D. 2007. E pluribus unum: Diversity and community in the twenty-first century. The 2006 Johan Skytte prize lecture. Scandinavian Political Studies 30(2):137-174. 2000. Bowling Alone: The Collapse and Revival of American Community. New York: Simon \& Schuster.

Randall, James E. and R. Geoff Ironside. 1996. Communities on the edge: An economic geography of resource-dependent communities in Canada. The Canadian Geographer 40(1):17-35. 
Reese, Michael Henry and John C. Cummings. 1979. Energy impacted housing. Pp. 63-78 in J. Davenport III and J.A. Davenport, eds., Boom Towns and Human Services. Laramie, WY: University of Wyoming.

Regional Municipality of Wood Buffalo. 2012. Our Sustainable Future: City Centre Area Redevelopment Plan - Bylaw 003/12. www.woodbuffalo. ab.ca.

2011. RE: Joint Review Panel Invites Public Comment for the Proposed Jackpine Mine Expansion Project (ERCB Application No. 1554388, CEAA Registry Reference No. 10-05-59540). http://www.ceaa.gc.ca/050/ documents/53587/53587E.pdf.

Rose, Nikolas S. 1999. Powers of Freedom: Reframing Political Thought. Cambridge: Cambridge University Press.

Ryser, Laura and Greg Halseth. 2011. Housing costs in an oil and gas boom town: Issues for low-income senior women living alone. Journal of Housing for the Elderly 25(3):306-325.

Schofield, Barry. 2002. Partners in power: Governing the self-sustaining community. Sociology 36(3):663-683.

Shandro, Janis A., Marcello M. Veiga, Jean Shoveller, Malcolm Scoble, Mieke Koehoorn. 2011. Perspectives on community health issues and the mining boom-bust cycle. Resources Policy 36(2):178-186.

Shever, Elana. 2008. Neoliberal associations: Property, company, and family in the Argentine oil fields. American Ethnologist 35(4):701-716.

Shields, Rob. 2012. Feral suburbs: Cultural topologies of social reproduction, Fort McMurray, Canada. International Journal of Cultural Studies 15(3):205-215.

1991. Places on the Margin: Alternative Geographies of Modernity. London: Routledge.

Tönnies, Ferdinand. [1887]1957. Community and Society (Gemeinschaft und Gesellschaft). C.P. Loomis, trans. and ed. East Lansing, MI: Michigan State University Press.

Turner, Terisa E. and Leigh S. Brownhill. 2004. Why women are at war with Chevron: Nigerian subsistence struggles against the international oil industry. Journal of Asian and African Studies 39(1-2):63-93.

Vaisey, Stephen. 2007. Structure, culture, and community: The search for belonging in 50 urban communes. American Sociological Review 72(6):851873.

Watts, Michael J. 2006. The sinister political life of community: Economies of violence and governable spaces in the Niger Delta, Nigeria. Pp. 101-142 in G.W. Creed, ed., The Seductions of Community: Emancipations, Oppressions, Quandaries. Santa Fe, NM: School of American Research Press. 
Williamson, Thad, David L. Imbroscio, and Gar Alperovitz. 2002. Making a Place for Community: Local Democracy in a Global Era. New York: Routledge.

Young, Nathan and Ralph Matthews. 2007. Resource economies and neoliberal experimentation: The reform of industry and community in rural British Columbia. Area 39(2):176-185. 